\title{
Nitelikli Mısır Popülasyonlarında Önemli Tane Kalite Özellikleri İçin Gen Etkisi, Heterosis ve Korelasyon Analizleri
}

\author{
Halil Uysal $^{*}$ (iD Fatih Kahrıman $^{1}$ \\ ${ }^{1}$ Çanakkale Onsekiz Mart University, Faculty of Agriculture, Department of Field Crops, 17020, Çanakkale, Turkey \\ *Sorumlu Yazar: haliluysal1991@ hotmail.com
}

Geliş Tarihi: 29.01.2021

Kabul Tarihi: 16.03.2021

\section{$\ddot{O} z$}

$\mathrm{Bu}$ araştırma nitelikli mısır popülasyonlarında verim ve bazı tane kalite özellikleri (yağ oranı, protein oranı, lisin içeriği, triptofan içeriği, oleik asit içeriği, karotenoid içeriği) kalıtımının incelenmesi 1slah programlarına uygun kaynak materyallerin belirlenmesi amacıyla yürütülmüştür. Çalışmada 4 nitelikli ebeveyn ile 2015 ve 2016 yıllarında Nesil Ortalama Analizine (NOA) uygun olarak hazırlanan 6 farklı popülasyona ait 6 nesil (E1, E2, F1, F2, GM1 ve GM2) materyal olarak kullanılmıştır. Tarla denemesi 2018 y1lında tesadüf blokları deneme desenine göre üç tekerrürlü olarak Çanakkale ilinde yürütülmüştür. Çalışmada tek bitki verimi, yă̆ oranı, protein oranı, lisin içeriği, triptofan içeriği, oleik asit içeriği, karotenoid içeriği hakkında ölçümler yapılmıştır. Toplanan veriler Nesil Ortalama Analizine (NOA) uygun istatistik model kullanılak analiz edilmiştir. $\mathrm{Bu}$ analizler ile incelenen özelliklerin değişiminde rol oynayan gen etkilerinin yanı sıra 1slah çalışmaları için kaynak materyal olarak kullanılabilecek popülasyonlar belirlenmiştir. Ayrıca incelenen özellikler için heterosis ve hetebeltiosis değerleri hesaplanmıştır. Özellikler arası korelasyonlar tüm veriler üzerinden ve popülasyon düzeyinde hesaplanarak popülasyon düzeyindeki değişimler irdelenmiştir. İncelenen özelliklerden verim ve karotenoid içeriğinde dominans genlerin diğer kalite özelliklerinde ise eklemeli genlerin kontrolünde olduğu gözlenmiştir. IHO $\times$ PR ve IHP $\times$ PR popülasyonlarının incelenen özellikler bakımından ümitvar kaynak materyaller olabileceği belirlenmiştir. Ortalama heterosis ve heterobeltiosis değerleri, incelenen özelliklerden tek bitki verimi ve karotenoid içeriği için pozitif yönde, diğer özelliklerden ise negatif yönde bulunmuştur. Bazı ailelerde verim ile birlikte tane kalite özelliklerinin geliştirilebileceği anlaşılmıştır.

Anahtar kelimeler: Tane Kalitesi, Biyokimyasal Kompozisyon, Zea Mays

\section{Gene Action, Heterosis and Correlation Studies in Different Specialty Maize Populations for Important Kernel Quality Traits}

\section{Abstract}

This research was carried out in order to i) examine the yield and some grain quality characteristics (oil ratio, protein ratio, lysine content, tryptophan content, oleic acid content, carotenoid content) in speciality maize populations, and ii) to determine the appropriate source materials for breeding programs. Six generations (P1, P2, F1, F2, BC1 and BC2) belonging to 6 different populations prepared in accordance with Generation Mean Analysis (GMA) in 2015 and 2016 with 4 qualified parents were used as material. The field trial was conducted in Çanakkale province in 2018 with three replications according to the randomized complete block design. Measurements were made on the yield of a single plant, oil ratio, protein ratio, lysine content, tryptophan content, oleic acid content, and carotenoid content. The collected data were analyzed using a statistical model for GMA. With these analyzes, the populations that can be used as source material for breeding studies, as well as the gene effects that play a role in the change of the examined traits, were determined. In addition, heterosis and hetebeltiosis values were calculated for the investigated traits. The correlations between traits were calculated over all data and at the population level and examined by populations. Among the traits examined, it was observed that dominance genes in yield and carotenoid content were under the control of additive genes in other quality traits. It has been determined that $\mathrm{IHO} \times \mathrm{PR}$ and $\mathrm{IHP} \times \mathrm{PR}$ populations can be promising source materials in terms of the traits examined. The average heterosis and heterobeltiosis values were found to be positive for single plant yield and carotenoid content, while they were found to be negative for other traits. It has been understood that grain quality traitss can be improved with yield in some families.

Keywords: Kernel Quality; Biochemical Composition; Zea mays

\section{Giriş}

Mısır dünyada ve ülkemizde temel tarımsal ürünler arasındadır ve mısırda tane kalitesinin artırılması hem insan hem de hayvan beslenmesi için önem arzetmektedir. Tana kalitesinin değişsimi 
başlıca yağ ve protein oranı ile bu bileşenlerin yapıtaşlarındaki değişimle ilişkilendirilmektedir (Egesel ve ark., 2011). Mısırda tane kalitesinin artırılması için bu özellikler üzerine yoğun şekilde sslah çalışmaları yürütülmektedir.

Mısır tanesinde protein oranı genotipik özelliklerden etkilenmektedir ve normal misır tiplerinde \% 8-11 arasında değişmektedir. Mısırda tane kalitesinin artırılması amacıyla protein oranının artırılmasından ziyade, protein kalitesinin artırılmasına ihtiyaç vardır (Vasal, 2000). Mısır tanesinde proteinlerin büyük bir kısmını (\%40-60) prolaminler oluşturmakta ve bu gruba zein proteinleri adı verilmektedir (Pollak ve Scott, 2005). Oransal olarak yüksek miktarda bulunan bu protein grubunun lisin ve triptofan gibi esansiyel aminoasitler bakımından fakir olması misır tanesinin besleyicilik değerini düşürmektedir. Bu durum mısırın besleyicilik değerini olumsuz yönde etkileyen önemli sorunlardan birtisidir ve bu sorunu çözmek amaciyla floury-2 ve opaque-2 tip misırlar geliştirilmiş ve lisin ve triptofan içeriği bakımından yüksek genotiplerin sslahı mümkün olmuştur. Yürütülen yoğun çalışmalar sonucunda ise bu genotiplerin melezleriyle Kalite Protein Mısır (QPM:Quality Protein Maize) özellikte yeni mısır tipleri geliştirilmiştir.

Yağ oranı mısırda tane kalitesini belirleyen diğer önemli bir unsurdur. Normal mısır tiplerinde \%3-5,5 arasında yă̆ bulunmaktadır ve yağ oranının artışı, mısır tanesinin beslenme açısından enerji değerini önemli ölçüde artırmaktadır. Mısırda yağ oranının artırılması için farklı ülkelerde çalışmalar yapılmış ve önemli başarılara ulaşılmıştır. Bu amaçla yürütülen 1slah programları içerisinde Illinois Long Term Selection Experiment çalışması örnek gösterilebilir. Bu çalışma sayesinde tane yağ içeriği \%12'yi aşan materyaller geliştirilmiştir. Bu konudaki ilerlemeler yağ bitkileri içerisinde yer alamayan mısırdan bitkisel yă̆ eldesini artırmıştır. Yağ oranının artırılmasının yanı sıra yă̆ kalitesinin geliştirilmesi mısır ıslah çalışmalarının önemli amaçlarından birisidir (Pollak ve Scott, 2005). Yağlık mısır genotiplerinin soya, ayçiçeği ve zeytin gibi yağlık bitkilerle alternative olabilmesi için mısır yağında doymuş yağ içeriğinin düşürülmesi, oleik asit içeriğinin artırılması ve doymamış yağ içeriğinin artırılmasına ihtiyaç vardır. Normal mısır tiplerinde \%10 palmitik, \%2 stearik, \%25 oleik, \%62 linoleik ve \%1 linolenik asit bulunmaktadır (Pollak ve Scott, 2005). Mısır yağında oleikasit içeriğinin artırılması özellikle endüstriyel kullanım için istenen niteliklerden birisidir. Mısırda yă kalitesini artırmaya yönelik çalışmalar mısır sslahı ile ilgilenen uluslararası düzeyde çalışmalar yapılmaktadır. Ülkemizde mısır hem tohumluk hem de ürün olarak stratejik ürünler arasındadır. Ülkemizde mısır yağı tüketiminin ayçiçeği ve zeytinyağından sonra üçüncü sırada olması (Yayar ve Bal, 2007) yağlık mısır genotiplerinin geliştirilmesini daha stratejik hale getirmektedir. Ülkemizde yüksek ya da tatminkâr verim değerlerine sahip yüksek yağlı mısır çeşitlerinin geliştirilmesi yağlık mısır üretimini artırabilir ve bu amaçla özel üretim yapmayı teşvik edebileceği bildirilmiştir (Öz ve Kapar, 2007).

Mısırda tane kalitesini beliryeci ikincil bileşenler de öenmli etkilere sahiptir. Mısır tanesinde doğal olarak sentezlenen ikinci bileșenler arasında karotenoidler, fenolikler ve antosiyaninler yer almaktadır (Lopez-Martinez ve ark., 2009). Bu bileşiklerin doğal olarak mısırda sentezlebilmesi ve diğer tahul türleri ile kıyaslandığında daha fazla miktarda bulunması nedeniyle mısıra olan ilgili artırmaktadır. İkincil bileşenlerden olan karotenoidler misır tanesine sarı ve turuncu rengini veren bileşiklerdir. Kanatlı hayvan beslemede yaygın olarak kullanılan mısırda bu bileşiklerin miktarının artırılması arzu edilmektedir. Karotenoid içeriğinin diğer tahıl türlerinde göre mısırda yüksek oluşu (Panfili ve ark., 2004) beslenme açısından önemli avantajlar kazandırmaktadır. Diğer taraftan sağlık açısından da yüksek karotenoid içeren mısır tiplerinin önemli faydaları olduğu rtapor edilmiştir (Howe ve Tanumihardjo, 2006). Bu nedenler ile karotenoid içeriğinin mısırda artırılması, uluslararası 1slah programlarının amaçlarından birisi haline gelmiştir.

Tane kalitesine yönelik ıslah programlarının başarıya ulaşabilmesi için öncelikle bu programlarda kullanılabilecek uygun başlangıç materyallerinin belirlenmesi gerekmektedir. Bu amaçla mısır bitkisinde farklı özellikler için gen etkilerinin belirlenmesi ve sslah çalışmalarında kaynak materyal olarak kullanılabilecek genotiplerin tespiti için farklı araştırmalar yürütülmüsştür. Literatürde yer alan bu amaçla yürütülen çalışmalar dikkate alındığında, mısırda verim ile ilgili bitkisel özellikler (Shahrokhi ve ark., 2011; Haq ve ark., 2013; Sher ve ark., 2012; Kahriman ve ark., 2015a), bazı kalite özellikleri (Kahriman ve ark., 2015b) ve hastalıklara dayanıklılık (Mbogo ve ark., 2015) gibi konularda çalışmaların yapıldığı dikkat çekmektedir. Bu çalışmalarda Nesil Ortalama Analizi (NAO) kullanılmış olup, bu yöntemde diğer analiz yöntemlerinde detaylandırılamayan epistatik 
interaksiyonlar bu yöntem sayesinde ayrıntılı şekilde hesaplanabilmektedir. Mevcut bilimsel literatürdeki yayınlar dikkate alındığında, uluslararası bilimsel literatürde mısırda tane kalitesine yönelik olarak yürütülen genetik araştırmaların verim ve bitkisel özelliklere yönelik çalışmalara göre nispeten az sayıda olduğu söylenebilir. Ülkemizde yürütülen sslah çalışması niteliğindeki araştırmalarda ise tane kalitesine yönelik oldukça sınırlı çalışma mevcuttur.

Bu çalışmanın amacı tane kalite özellikleri bakımından nitelikli ebeveynlerle oluşturulmuş 6 farklı popülasyonda tek bitki verimi ve bazı tane kalite özellikleri bakımından seleksiyona uygun popülasyonların seçilmesi ve incelenen özelliklerin kalıtımı ile bu özellikler için kullanılan materyalde incelenen özellikler arası ilişkilerin ve heterosis değerlerinin irdelenmesi hedeflenmiştir.

\section{Materyal ve Yöntem \\ Deneme Materyali ve Denemenin Yürütülmesi \\ Materyal}

Araştırmada 4 farklı nitelikli mısır ebeveyni ile oluşturulan altı farklı popülasyonun farklı nesillerine ait materyaller tohumluk olarak kullanılmıştır. Bu materyal seti 205 ve 2016 yıllarında tohumluk üretim denemelerinde oluştulmuştur. Çalışmada kullanılan materyaller hakkında genel bilgiler Çizelge 1'de sunulmuştur.

Çizelge 1. Araştırmada kullanılan tohumluk materyaller

\begin{tabular}{|c|c|c|c|c|c|}
\hline $\begin{array}{l}\text { E1 } \\
\text { (Ana } \\
\text { Ebeveyn) }\end{array}$ & $\begin{array}{l}\text { E2 } \\
\text { (Baba } \\
\text { Ebeveyn) }\end{array}$ & F1 & $\mathrm{F} 2$ & $\begin{array}{l}\text { GM1 } \\
\text { (F1'in Ana ile Geri } \\
\text { Melezi) }\end{array}$ & $\begin{array}{l}\text { GM2 } \\
\text { (F1'in Baba ile Geri } \\
\text { Melezi) }\end{array}$ \\
\hline Q2 & IHO & $\mathrm{Q} 2 \times \mathrm{IHO}$ & $\mathrm{Q} 2 \times \mathrm{IHO}$ & $(\mathrm{Q} 2 \times \mathrm{IHO}) \times \mathrm{Q} 2$ & $(\mathrm{Q} 2 \times \mathrm{IHO}) \times \mathrm{IHO}$ \\
\hline Q2 & IHP & $\mathrm{Q} 2 \times \mathrm{IHP}$ & $\mathrm{Q} 2 \times \mathrm{IHP}$ & $(\mathrm{Q} 2 \times \mathrm{IHP}) \times \mathrm{Q} 2$ & $(\mathrm{Q} 2 \times \mathrm{IHP}) \times \mathrm{IHP}$ \\
\hline Q2 & PR & $\mathrm{Q} 2 \times \mathrm{PR}$ & $\mathrm{Q} 2 \times \mathrm{PR}$ & $(\mathrm{Q} 2 \times \mathrm{PR}) \times \mathrm{Q} 2$ & $(\mathrm{Q} 2 \times \mathrm{PR}) \times \mathrm{PR}$ \\
\hline $\mathrm{IHO}$ & IHP & $\mathrm{IHO} \times \mathrm{IHP}$ & $\mathrm{IHO} \times \mathrm{IHP}$ & $(\mathrm{IHO} \times \mathrm{IHP}) \times \mathrm{IHO}$ & $(\mathrm{IHO} \times \mathrm{IHP}) \times \mathrm{IHP}$ \\
\hline IHO & PR & $\mathrm{IHO} \times \mathrm{PR}$ & $\mathrm{IHO} \times \mathrm{PR}$ & $(\mathrm{IHO} \times \mathrm{PR}) \times \mathrm{IHO}$ & $(\mathrm{IHO} \times \mathrm{PR}) \times \mathrm{PR}$ \\
\hline IHP & PR & $\mathrm{IHP} \times \mathrm{PR}$ & $\mathrm{IHP} \times \mathrm{PR}$ & $(\mathrm{IHP} \times \mathrm{PR}) \times \mathrm{IHO}$ & $(\mathrm{IHP} \times \mathrm{PR}) \times \mathrm{PR}$ \\
\hline
\end{tabular}

\section{Tarla Denemesi}

Tarla denemesi Çanakkale Onsekiz Mart Üniversitesi, Ziraat Fakültesi Çiftliği, Bitkisel Üretim Araştırma ve Uygulama Birimi'nde tesadüf blokları deneme tertibine uygun şekilde üç tekerrürlü olarak yürütülmüştür. Denemede kullanılan ebeveynler ve hibritler 2 siralı parsellere, F1'ler ve gerimelezler ise 4 sıralı parsellere 2018 yılında mayıs ayının ilk haftasında ekilmiştir. Ekim sıklığı $70 \times 20 \mathrm{~cm}$ olacak şekilde ayarlanmıştır ve dekara yaklaşık 7140 bitki hedeflenerek ekim işlemi gerçekleştirilmiştir. Çıkışın garanti altına alınması için her sıraya iki katı tohum atılmış ve çıkış sonrası bitkiler 15-20 cm olduğunda seyreltme yapılmıştır. Sulama damla sulama sistemi ile bitkilerin su ihtiyaçları ve toprak yapısı dikkate alınarak yapılmıştır. Deneme alanından 0-30 cm derinlikten alınan toprak önrklerine ilişkin analiz sonuçlarına göre, denemenin kurulduğu alanın organik maddece fakir, potasyum bakımından yeterli, hafif alkali, tuzsuz ve orta kireçli bir yapıya sahip olduğu görülmektedir (Çizelge 2). Gübreleme toprak analizi sonuçlarına göre damla sulama ile birlikte yapılmıştır. İlk sulamadan itibaren çiçeklenme zamanına kadar hesaplanan azot eşit miktarda, fosfor ve potasyum ise ekimin ardından yapılan ilk ve ikinci sulamada verilmiştir. Deneme alanı iklim özellikleri bakımından mısır yetiştiriciliğine uygun ve Çanakkale ilinin uzun yıllar iklim değerlerine yakın değerler sergilemiştir (Çizelge 3).

Çizelge 2. Deneme alanının genel toprak özellikleri

\begin{tabular}{llllll}
\hline $\mathrm{pH}$ & $\mathrm{EC}(\mathrm{mS} \mathrm{cm}-1)$ & Kireç (\%) & Organik Madde $(\%)$ & $\mathrm{P}(\mathrm{kg} \mathrm{da}-1)$ & $\mathrm{K}(\mathrm{kg} \mathrm{da}-1)$ \\
\hline 8,21 & 0,53 & 10,2 & 1,22 & 1,8 & 57 \\
Hafif Alkali & Tuzsuz & Orta Kireçli & $\mathrm{Az}$ & $\mathrm{Az}$ & Yeterli \\
\hline
\end{tabular}


Çizelge 3. Denemenin yürürüldüğü yılda Çanakkale ilinin iklim özellikleri (MGM, 2019)

\begin{tabular}{lllllll}
\hline İklim Özellikleri & Mayıs & Haziran & Temmuz & Ağustos & Eylül & Ekim \\
\hline Ortalama Sıcaklık $\left({ }^{\circ} \mathrm{C}\right)$ & 19,6 & 23,2 & 26,5 & 27,1 & 22,0 & 17,5 \\
En Yüksek Sıcaklık $\left({ }^{\circ} \mathrm{C}\right)$ & 24,3 & 28,3 & 31,5 & 32,3 & 26,8 & 21,1 \\
En Düşük Sıcaklık $\left({ }^{\circ} \mathrm{C}\right)$ & 15,9 & 19,1 & 21,6 & 22,7 & 18,0 & 14,6 \\
Ortalama Bağı̆l Nem $(\%)$ & 70,1 & 63,9 & 59,6 & 56,5 & 63,2 & 72,5 \\
Toplam Yağış $(\mathrm{mm})$ & 30,7 & 17,8 & 16,1 & 0,0 & 71,5 & 51,1 \\
\hline
\end{tabular}

Deneme materyallerinin tane kalite özellikleri bakımından doğru şekilde değerlendirilebilmesi için kontrollü tozlama yöntemlerinden yararlanılmıştır. $\mathrm{Bu}$ amaçla çiçeklenme zamanında tarla kontrolleri yapılarak parsellerin orta kısmından tesadüfi olarak seçilen bitkilerin koçanları koruma altına alınmıştır. Tozlama işlemi sabah saatlerinde (8:00-10:00) arasında gerçekleştirilmiştir. Bu amaçla bir gün öncesinden konulan tepe püskülü kağıtlarında toplanan polenler tam korumalı olarak aynı bitkilerin koçanlarına aktarılmıştır (Anonim, 2016). Bitkiler hasat olgunluğuna geldiğinde elle hasat yapılmıştır ve her materyale ait kendilenmiş koçanlar toplanarak file torbalara alınmıştır. Hasatta ebeveyn hatlar ve F1 neslinde her genotip için 10'ar adet, F2 nesli için 60 adet, geri melez nesilleri için ise 30'ar adet örnek alınmıştır. Tek bitki verimlerinin ölçümünde nesillere göre aynı sayılarda alınan açıkta tozlanmış koçan örnekleri kullanılmıştır. Toplanan örnekler laboratuvar analizlerinde kullanılmak üzere hazırlanana kadar +5 C'de muhafaza edilmiştir.

\section{İncelenen Özellikler}

Tarla denemelerinden alınan örnekler öncelikle tanelenmiştir ve her koçana ait örnekler hava geçirmez torbalar içerisinde muhafaza edilmiştir. Açıkta tozlanmaya bırakılmış koçan örneklerinden tek bitki verimi, kontrollü tozlama örneklerinden ise tane içeriğine yönelik ölçümler yapılmıştır. Tek bitki veriminin tespiti için tarla denemelerinde açıkta tozlamaya bırakılmış koçan örnekleri tanelenmiş ve ardından örneklerin ağırlıkları alınarak tek bitki verimleri TTSM (2010) klavuzuna uygun olarak belirlenmiştir. Kontrollü tozlama örnekleri taneleme işleminin ardından laboratuvar tipi değirmende $0,5 \mathrm{~mm}$ elek çapında homojen bir şekilde ögütülmüştür. Ögütülen örnekler laboratuvar analizlerinde kullanılmak üzere muhafaza edilmiştir.

Örneklerin yağ ve protein içerikleri NIR spektroskopi cihazında geliştirilen lokal kalibrasyon modeli kullanılarak belirlenmiştir (Egesel ve Kahrıman, 2012). Oleik asit içeriğinin tespiti için öğ̈̈tülmüş örneklerden dietil eter ile yağ çıkarma işlemi gerçekleştirilmiştir. Çıkarılan yağ örnekleri NIR cihazında analiz edilmiş ve örneklerin oleik asit, linoleik asit, toplam tekli doymamış yağ asiti (MUFA) ve toplam çoklu doymamış yağ asiti miktarları (PUFA) tespit edilmiştir. Bu tespitler birimimizde daha önceki çalışmalarda geliştirilen NIR kalibrasyon modeli kullanılarak gerçekleştirilmiştir (Egesel ve ark., 2016). Örneklerin lisin ve triptofan içerikleri Galicia ve ark. (2009) tarafından geliştirilen kolorimetrik yönteme uygun olarak analiz edilmiştir. Karotenoid analizleri Rodriguez-Amaya ve Kimura (2004) tarafından geliştirilen spektrofotometrik metoda uygun olarak gerçekleştirilmiştir.

\section{Verilerin Değerlendirilmesi ve İstatistik Analizler \\ Nesil Ortalama Analizi}

Ölçüm alınan özellikler ile ilgili verilerin analizinde SAS V8 paket programında (SAS Institute, 1999) geliştirilmiş makrodan (Gusmini ve Wehner, 2003) yararlanılmıştır. Bu makrolar NOA yapılmasına imkân veren program eklentileridir. Kullanılan makrolarda aşağıdaki parametreler hakkında tespitler yapılmıştır.

Varyans Bileșenleri: Varyans bileşenleri aşağıdaki formüllere göre $(1,2,3,4)$ tespit edilmiştir.

Eklemeli Varyans $(V A)=2 * V F 2-(V G M 1-V G M 2)$

Fenotipik Varyans $(V P)=V F 2$

Genotipik Varyans $(V G)=V P-V E$

Dominans Varyans $(V D)=V G-V A$

Formüllerde; VA eklemeli varyans1, VE çevresel varyans1, VP fenotipik yani toplam varyansı, VG genotipik varyans1, VD dominans varyansı göstermektedir. Bu bileşenleri hesaplamak için farklı nesillerde hesaplanan varyanslardan yararlanılmıştır. Formülllerde VF2 F2 nesline ait varyans1, VGM1 ve VGM2 gerimelezlere ait varyansları göstermektedir. 
Kalıtım Dereceleri: Geniş $\left(\mathrm{H}^{2}\right)$ ve dar $\left(\mathrm{h}^{2}\right)$ anlamda kalıtım derecesinin tahmini için genetik varyansın toplam varyans içerisindeki payı ve eklemeli varyansın toplam varyans içerisindeki payı hesaplanmıştır $(5,6)$. Her bir kombinasyon ve özellik için bu hesaplama makro vasıtasıyla aşağıdaki formüllere göre $(5,6)$ gerçekleştirilmiştir.

Geniş Anlamda Kalıtım Derecesi $\left(H^{2}\right)=\frac{V G}{V P}$

Dar Anlamda Kalıtım Derecesi $\left(h^{2}\right)=\frac{V A}{V P}$

Gen Etkilerinin Tahmini: İncelenen özelliklerde eklemeli (a), dominans (d) ve epistatik interaksiyonlara $(\mathrm{aa}+\mathrm{ad}+\mathrm{dd})$ ilişkin tahminlemeler yapılmıştır ve gen etkilerine ilişkin hesaplamalar aşağıdaki formüllere göre $(7,8,9,10,11,12)$ gerçekleştirilmiştir.

Ortalama $(m)=m F 2$

Eklemeli Etki $(a)=m G M 1-m G M 2$

Dominans Etki $(d)=(-0.5 *$ mGM1 $)-(0.5 *$ mGM2 $)+\mathrm{mF} 1-(4 * \mathrm{mF} 2)+(2 *$ mGM1 $)+(2 *$ mGM2)

Eklemeli + Eklemeli Epistatis $(a a)=-(4 * \mathrm{mF} 2)+(2 * \mathrm{mGM} 1)+(2 * \mathrm{mGM} 2)$ Eklemeli + Dominans Epistatis $(a d)=(-0.5 * \mathrm{mE} 1)+(0.5 * \mathrm{mE} 2)+\mathrm{mGM} 1-$ mGM2 Dominans + Dominans Epistatis $($ dd $)=\mathrm{mE} 1+\mathrm{mE} 2+(2 * \mathrm{mF} 1)+(4 * \mathrm{mF} 2)-[4 *$
$(\mathrm{mGM} 1+\mathrm{mGM} 2)]$

Formüllerde; mF2 F2 nesline ait ortalamay1, mE1 ana ebevyn ortalamasın1, mE2 baba ebeveyn ortalamasını, mF1 F1 nesline ait ortalamay1, mGM1 ana ebeveynle yapılan geri melez ortalamasını, mGM2 baba ebevynle yapılan gerimelez ortalamasını göstermektedir.

Seleksiyonla Sağlanabilecek Teorik İlerleme: Kalıtım derecesi ve seleksiyon sabiti yardımıyla her bir kombinasyon için incelenen her özellikte seleksiyonla sağlanabilecek ilerleme aşağıdaki formüle (13) göre tespit edilmiştir.

Genetik Ilerleme $($ GI $\% 5)=2.06 * h^{2} * \sqrt{V F 2}$

NOA'nden elde edilen sonuçlar dikkate alınarak kullanılan materyalde seleksiyona uygun popülasyonlar tespit edilmiştir. Özelliklerde rol oynayan gen etkisi ve özelliğe ait kalıtım derecesi dikkate alınarak hangi ıslah yönteminin kullanılmasının uygun olduğu belirlenmiştir. İleriki çalışmalarda kullanılması uygun bulunan her bir materyal için özelliklere göre değerlendirmeler yapılmış ve birden fazla özellik için ıslah çalışmalarında kullanım potansiyeli bulunan materyaller belirlenmeye çalışılmıştır.

Heterosis ve Heterobeltiosis Hesaplamaları

Çalışmada incelenen her özellik için tüm veriler üzerinden ve ailelere göre ayrı ayrı olmak üzere F1 neslinde heterosis ve heterobeltiosis değerleri Falconer ve Mackay (1996) tarafindan önerilen formüllere göre $(14,15)$ hesaplanmıştır.

Anaç Ortalamalarına Göre Heterosis $(A O H)=\frac{(F 1-A O)}{F 1} \times 100$

Üstün Anaca Göre Heterosis (Ü $A H)=\frac{(F 1-\tilde{U} A O)}{F 1} \times 100$

$\mathrm{Bu}$ formüllerde $\mathrm{F} 1, \mathrm{~F} 1$ nesline ait ortalamayı, AO, anaç ortalamasını, ÜAO, üstün anaca ait değeri göstermektedir. Heterosis ve heterobeltiosis hesaplamaları F1 ve ebeveyn ortalamaları üzerinden hesaplanmiştır.

\section{Korelasyon Analizleri}

Korelasyon analizlerinde incelenen özellikler arası ilişkiler tüm veri setleri üzerinden ve ailelere göre ayrı ayrı irdelenmiştir. Bu analizlerde SAS V8 programında Proc CORR komutu kullanılmış ve Pearson korelasyon katsayıları hesaplanmıştır (SAS Institute, 1999). Analiz sonuçları çizelgeler halinde sunulmuş ve korelasyonun katsayılarının önemlilik düzeyleri de çizelgeler üzerinde gösterilmiştir. $\mathrm{Bu}$ analizlerin yapılmasının temel amacı incelenen özellikler arasındaki ilişkilerin ailelere göre değişip değişmediğini ortaya koymaktır. 


\section{Bulgular ve Tartışma}

\section{Genetik Analizlere İlişkin Sonuçlar}

Kullanılan ailelerin dördünde dominans ikisinde eklemeli, ikisinde eklemeli+eklemeli ve birisinde ise dominans+dominans genlerin tek bitki veriminin kontrolünde rol oynadığı görülmektedir (Çizelge 4). Tek bitki veriminin dominans gen etkilerininin yanı sıra (Shahrokhi ve ark., 2013; Patil ve ark., 2016; Kahrıman ve Egesel, 2017) eklemeli genlerin de verimdeki değişimi kontrol ettiğini bildiren araştırmalar mevcuttur (Ma ve ark., 2007; Obeng-Bio ve ark., 2019). Diğer tarftan epistatik interaksiyonlar da tek bitki veriminin değişiminde etkili olduğunu rapor eden çalışmalara rastlanmaktadır (Sofi ve ark., 2006). Bu çalışmalarda elde edilen farklı sonuçların araştırmalarda kullanılan analiz yöntemine ve kullanılan materyaldeki farklılıklara atfetmek mümkündür. Yağ oranı için elde edilen sonuçlara göre, 6 aileden 4'ünde eklemeli etkilerin, 1'inde dominans etkilerin, 2'sinde eklemeli + eklemeli etkilerin, 2'sinde eklemeli + dominans etkilerin etkilerin önemli olduğu bulunmuştur. Yağ oranının eklemeli gen etkilerinin kontrolünde olduğu ve bu özelliğin yüksek kalıtım derecesine sahip olduğu bildirilmiştir (Kahrıman ve Egesel, 2017). Oleik asit içeriğinin büyük oranda eklemeli genlerin kontrolünde olduğu, bazı ailelerde ise dominans ve epistatik interaksiyonların bu özelliğin kalıtımında etkili rol oynadığı görülmüştür. Protein oranının değişiminde eklemeli genlerin baskın role sahip olduğu anlaşılmış, Q2 $\times$ IHP ve IHP $\times$ PR'de dominans ve epistatik interaksiyonların bu özelliğin değişimine etki ettiği anlaşılmıştır. Kahrıman ve Egesel (2012) mısırda protein içeriğinin eklemeli gen etkileri tarafından kontrol edildiğini belirtmişlerdir. Lisin içeriğinin değișimi üzerine eklemeli genlerin baskın role sahip olduğu, IHO $\times$ PR'de ise hesaplanan tüm gen etkilerinin değişimine neden olduğu görülmüştür. Hussain ve ark. (2015) lisin içeriğinin eklemeli geneler tarafından kontrol edildiğini bildirmişlerdir. Çalışmamızda kullanılan materyalden kaynaklanan nedenlerle gen etkilerinde farklılıklar meydana gelmiş olabilir. Kullanılan materyalde triptofan içeriğinin değişiminde başlıca eklemeli etkilerin ve bu etkilere bağlı epistatik interaksiyonların önemli bir role sahip oldukları anlaşılmıştır. Mısırda $8 \times 8$ dilalel set ile yürütülen bir araştırma sonucunda triptofan içeriğinin eklemeli genlerin kontrolünde olduğu rapor edilmiştir (Hussain ve ark., 2015). Karotenoid içeriğinin değişiminde dominans etkilerin önemli bir etkiye sahip olmadıkları, bazı ailelerde eklemeli ve epistatik interaksiyonların bu özelliğin değişiminde rol oynadığ tespit edilmiştir.

NOA'nde hesaplanan gen etkilerinin işaretleri ve önemlilik durumlarına göre incelenen özelliğin kalıtımında rol oynayan alleller hakkında değerlendirmeler yapılabilmektedir. Negatif dominans (d) etkiler dominant fenotipin olumsuz etkiye sahip allelleri bulundurduğunu, tam tersine pozitif yönde dominans etkiler ise olumlu allellerin dominant fenotipte bir araya geldiğine işaret etmektedir. Epistatik interaksiyonlardan dominans+dominans ile dominans etkiler için hesaplanan değerin işaretleri eş olduğunda komplimenter epistasis olduğu, zit olduğunda ise duplike epistasis olduğu kabul edilmektedir (Mather ve Jinks, 1982). Epistatik interaksiyonlardan eklemeli+eklemeli etkilerin negatif ya da pozitif yönde işarete sahip olması ebeveynlerde allel dağılımları hakkında bilgi vermektedir. Şayet $a+a$ etkisinin işareti negatif ve önemli bulunmuş ise, ebeveynlerde allelik dağılımların eşit olduğuna, pozitif ise istenen allelerin bir ebeveynde yoğunlaştığına işaret etmektedir (Mather ve Jinks, 1982). Bu bilgilere dayalı olarak çalışmada elde edilen sonuçlarlara göre incelenen özellikler üzerinde rol oynayan gen etkileri hakkında şu değerlendirmeler yapılabilir. Tek bitki verimi ve protein oranı için tüm popülayonlarda olumlu allellerin dominant fenotipkte toplandığı anlaşılmaktadır (Çizelge 4). Yağ oranı için dört ailede, oleik asit içeriği için iki ailede, lisin içeriği için beş ailede, triptofan içeriği için üç ailede ve karotenoid içeriği için beş ailede olumlu alleler dominant genotipte bulunmaktadır. İncelenen özelliklerden verim için tüm ailelerde, yağ için $\mathrm{IHO} \times \mathrm{IHP}$ ve IHP $\times \mathrm{PR}$ popülasyonlarında duplike epistatis gözlenmiştir Oleik asit oranı için Q2 $\times$ IHP ve Q2xPR popülasyonlarında, protein oranı için Q2 $\times$ IHP ve IHO $\times$ PR popülasyonları, lisin içeriği için $\mathrm{IHO} \times \mathrm{PR}$ popülasyonunda, triptofan içeriği için ve karotenoid içeriği için ise Q2×IHO popülsyonunda komplementer epistasis olduğu belirlenmiştir. Tane kalite özellikleri bakımından yukarıda belirtilen aileler dışındaki materyallerde ise duplike epistasis olduğu görülmüştür.

Çalışmada kullanılan popülasyonların farklı kalite özellikleri bakımından ıslah çalışmalarında kullanılabilecek kaynak materyal niteliği bulunan genoitpler belirlenmiştir. Tek bitki veriminin tüm ailelerde pozitif yönde seleksiyon ile geliştirilebileceği, bunun yanı sıra en yüksek ilerlemenin Q2 $\times$ PR'den elde edilebileceği görülmüştür. Yağ oranına yönelik seleksiyon ile $\mathrm{IHO} \times \mathrm{PR}$ ve IHP $\times$ PR'de pozitif yönde bir ilerleme sağlanabileceği görülmüştür. Oleik asit içeriğini artırmak 
amacıyla Q2 $\times$ IHO, IHO $\times$ PR ve IHP $\times$ PR'nin kaynak materyal olarak kullanılabileceği belirlenmiştir. Protein oranına yönelik 1slah çalışmalarında $\mathrm{Q} 2 \times \mathrm{PR}$ ve $\mathrm{IHO} \times \mathrm{PR}$ 'nin kaynak materyal olarak kullanılması durumunda, protein oranının pozitif yönde artırılabileceği görülmüştür. Lisin içeriği için yalnızca IHP $\times$ PR'da seleksiyon ile pozitif yönde bir ilerlemenin mümkün olduğu tespit edilmiştir. Triptofan içeriği bakımından $\mathrm{Q} 2 \times \mathrm{PR}$, IHO $\times \mathrm{PR}$ ve $\mathrm{IHP} \times \mathrm{PR}$ 'de pozitif yönde genetik ilerlemenin seleksiyon ile mümkün olduğu belirlenmiştir. Karotenoid içeriği için Q2×IHO, IHO $\times \mathrm{IHP}, \mathrm{IHO} \times \mathrm{PR}$ ve IHP×PR'de pozitif yönde genetik ilerlemenin mümkün olduğu anlaşılmıştır (Çizelge 4).

Çizelge 4. İncelenen özelliklere göre kullanılan ailelerde hesaplanan gen etkileri, kalıtım derecesi ve teorik genetik ilerleme değerleri.

\begin{tabular}{|c|c|c|c|c|c|c|c|c|c|}
\hline Verim & $\mathrm{m}$ & $\mathrm{a}$ & $\mathrm{d}$ & aa & $\mathrm{ad}$ & $\mathrm{dd}$ & $\mathrm{H}^{2}$ & $\mathrm{~h}^{2}$ & Gİ $\% 5$ \\
\hline $\mathrm{Q} 2 \times \mathrm{IHO}$ & $67,32 * *$ & $-12,3$ & $133,1 *$ & $101,2 *$ & $-34,4$ & $-122,7$ & 0,28 & 0,00 & 0,0 \\
\hline $\mathrm{Q} 2 \times \mathrm{IHP}$ & $90,11 * *$ & $57,8 * *$ & $114,5^{*}$ & 60,9 & 25,0 & $-132,6$ & 0,37 & 0,00 & 0,0 \\
\hline $\mathrm{Q} 2 \times \mathrm{PR}$ & $68,08 * *$ & $41,8 * *$ & $101,8 *$ & 64,5 & 12,6 & $-70,16$ & 0,00 & 0,00 & 0,0 \\
\hline $\mathrm{IHO} \times \mathrm{IHP}$ & $62,52 * *$ & 13,54 & $156,8 * *$ & $101,1 * *$ & 2,84 & $-186,4^{*}$ & 0,00 & 0,00 & 0,0 \\
\hline $\mathrm{IHO} \times \mathrm{PR}$ & $85,45^{* *}$ & 5,57 & 31,9 & $-12,9$ & $-1,61$ & $-57,99$ & 0,24 & 0,00 & 0,0 \\
\hline $\mathrm{IHP} \times \mathrm{PR}$ & $48,44 * *$ & 6,51 & 43,4 & 18,6 & 10,0 & $-55,91$ & 0,00 & 0,03 & 1,2 \\
\hline \multicolumn{10}{|l|}{ Yağ } \\
\hline $\mathrm{Q} 2 \times \mathrm{IHO}$ & $5,72 * *$ & $-4,11 * *$ & $3,37 *$ & $4,16 * *$ & $-0,72$ & $-2,61$ & 0,00 & 0,46 & 0,9 \\
\hline $\mathrm{Q} 2 \times \mathrm{IHP}$ & $4,56 * *$ & $-0,73$ & 0,85 & 0,93 & $-0,63$ & $-3,26$ & 0,84 & 1,00 & 4,2 \\
\hline $\mathrm{Q} 2 \times \mathrm{PR}$ & $3,90 * *$ & $0,64 * *$ & 1,35 & $1,22 *$ & 0,58 & $-1,42$ & 0,00 & 1,00 & 1,3 \\
\hline $\mathrm{IHO} \times \mathrm{IHP}$ & $7,69 * *$ & $1,83 * *$ & $-0,77$ & $-0,22$ & $-1,46 *$ & $-0,91$ & 0,05 & 0,55 & 1,1 \\
\hline $\mathrm{IHO} \times \mathrm{PR}$ & $7,39 * *$ & $4,79 * *$ & 0,59 & $-0,21$ & $2,11 * *$ & $-0,69$ & 0,33 & 0,00 & 0,0 \\
\hline $\mathrm{IHP} \times \mathrm{PR}$ & $4,28 * *$ & $-0,25$ & $-0,58$ & $-0,27$ & $-0,41$ & $-0,43$ & 0,22 & 0,00 & 0,0 \\
\hline \multicolumn{10}{|l|}{ Oleik } \\
\hline $\mathrm{Q} 2 \times \mathrm{IHO}$ & $32,9 * *$ & $-14,6 * *$ & 17,92 & 18,72 & $-9,11$ & $-15,10$ & 0,12 & 0,00 & 0,0 \\
\hline $\mathrm{Q} 2 \times \mathrm{IHP}$ & $32,2 * *$ & $8,69 * *$ & $-0,93$ & 4,39 & $7,83^{*}$ & $-17,76$ & 0,55 & 1,00 & 13,6 \\
\hline $\mathrm{Q} 2 \times \mathrm{PR}$ & $26,8 * *$ & $8,27 * *$ & 3,97 & 3,38 & 4,46 & 5,78 & 0,00 & 1,00 & 11,6 \\
\hline $\mathrm{IHO} \times \mathrm{IHP}$ & $39,2 * *$ & 1,89 & $-16,12$ & $-13,11$ & $-4,42$ & 15,52 & 0,26 & 0,00 & 0,0 \\
\hline $\mathrm{IHO} \times \mathrm{PR}$ & $42,9 * *$ & $14,01 * *$ & $-10,6$ & $-23,94 *$ & 7,49 & 32,09 & 0,71 & 0,81 & 13,1 \\
\hline $\mathrm{IHP} \times \mathrm{PR}$ & $32,4 * *$ & $-0,32$ & $-24,8 * *$ & $-18,28 * *$ & $-3,27$ & 9,18 & 0,00 & 0,45 & 3,3 \\
\hline \multicolumn{10}{|l|}{ Protein } \\
\hline $\mathrm{Q} 2 \times \mathrm{IHO}$ & $10,79 * *$ & $-1,53 *$ & 1,78 & 2,32 & $-0,66$ & $-0,98$ & 0,49 & 0,15 & 0,5 \\
\hline $\mathrm{Q} 2 \times \mathrm{IHP}$ & $12,71 * *$ & $-3,96 * *$ & 0,80 & 1,72 & $-0,85$ & 0,72 & 0,69 & 1,13 & 4,1 \\
\hline $\mathrm{Q} 2 \times \mathrm{PR}$ & $9,63 * *$ & 0,12 & 2,38 & $3,05 * *$ & 0,42 & $-0,32$ & 0,00 & 0,00 & 0,0 \\
\hline $\mathrm{IHO} \times \mathrm{IHP}$ & $14,42 * *$ & $-2,03 *$ & 0,81 & 3,35 & 0,21 & $-9,17$ & 0,27 & 0,04 & 0,2 \\
\hline $\mathrm{IHO} \times \mathrm{PR}$ & $11,36 * *$ & $1,09 *$ & 0,87 & 0,82 & 0,40 & 2,59 & 0,00 & 0,00 & 0,0 \\
\hline $\mathrm{IHP} \times \mathrm{PR}$ & $12,49 * *$ & $2,72 * *$ & 3,50 & $5,51 * *$ & $-0,09$ & $-6,94$ & 0,60 & 0,32 & 0,8 \\
\hline \multicolumn{10}{|l|}{ Lisin } \\
\hline $\mathrm{Q} 2 \times \mathrm{IHO}$ & $0,582 * *$ & $-0,083 * *$ & $0,220^{*}$ & $0,189 *$ & $-0,006$ & $-0,149$ & 0,34 & 0,00 & 0,00 \\
\hline $\mathrm{Q} 2 \times \mathrm{IHP}$ & $0,562 * *$ & $-0,082 * *$ & 0,143 & 0,127 & $-0,086^{*}$ & $-0,295$ & 0,12 & 1,05 & 0,119 \\
\hline $\mathrm{Q} 2 \times \mathrm{PR}$ & $0,481 * *$ & $0,032 *$ & $-0,123$ & $-0,071$ & 0,026 & $0,281 *$ & 0,79 & 1,36 & 0,153 \\
\hline $\mathrm{IHO} \times \mathrm{IHP}$ & $0,633 * *$ & 0,019 & 0,057 & 0,080 & $-0,046$ & $-0,296$ & 0,39 & 0,66 & 0,094 \\
\hline $\mathrm{IHO} \times \mathrm{PR}$ & $0,575^{* *}$ & $0,161 * *$ & 0,075 & 0,041 & 0,068 & 0,045 & 0,42 & 0,00 & 0,00 \\
\hline $\mathrm{IHP} \times \mathrm{PR}$ & $0,496 * *$ & 0,036 & 0,167 & 0,222 & 0,040 & $-0,409$ & 0,73 & 0,94 & 0,161 \\
\hline \multicolumn{10}{|l|}{ Triptofan } \\
\hline $\mathrm{Q} 2 \times \mathrm{IHO}$ & $0,0379 * *$ & $-0,011 * *$ & 0,0028 & $0,020^{*}$ & $-0,014^{*}$ & $0,020 *$ & 0,00 & 0,00 & 0,00 \\
\hline $\mathrm{Q} 2 \times \mathrm{IHP}$ & $0,0384 * *$ & $-0,011 * *$ & $-0,0032$ & 0,011 & $-0,023 * *$ & $0,006 *$ & 0,11 & 1,00 & 0,014 \\
\hline $\mathrm{Q} 2 \times \mathrm{PR}$ & $0,0284 * *$ & 0,0012 & $-0,0107$ & 0,003 & $-0,019 *$ & $0,032 *$ & 0,00 & 0,33 & 0,002 \\
\hline $\mathrm{IHO} \times \mathrm{IHP}$ & $0,0483 * *$ & $-0,0001$ & $-0,0004$ & 0,008 & $-0,009$ & $-0,022 *$ & 0,00 & 0,77 & 0,011 \\
\hline $\mathrm{IHO} \times \mathrm{PR}$ & $0,0400 * *$ & $0,0149 * *$ & 0,0088 & 0,002 & 0,002 & $0,001 *$ & 0,00 & 0,00 & $-0,010$ \\
\hline $\mathrm{IHP} \times \mathrm{PR}$ & $0,0329 * *$ & $0,0039 *$ & 0,0252 & $0,025 * *$ & $-0,004$ & $-0,050 *$ & 0,00 & 0,96 & 0,012 \\
\hline \multicolumn{10}{|l|}{ Karotenoid } \\
\hline $\mathrm{Q} 2 \times \mathrm{IHO}$ & $28,53 * *$ & 2,46 & $-9,85$ & $-25,87^{*}$ & $-2,35$ & $-6,79$ & 0,28 & 0,00 & 0,00 \\
\hline $\mathrm{Q} 2 \times \mathrm{IHP}$ & $23,56 * *$ & $8,04 * *$ & $21,31 *$ & 3,01 & 3,23 & $-40,11 *$ & 0,28 & 0,52 & 6,3 \\
\hline $\mathrm{Q} 2 \times \mathrm{PR}$ & $25,62 * *$ & $-0,20$ & 13,30 & $-3,43$ & $-2,66$ & $-29,27$ & 0,78 & 1,17 & 17,6 \\
\hline $\mathrm{IHO} \times \mathrm{IHP}$ & $2,73 * *$ & 1,04 & 4,14 & 1,48 & 1,03 & $-4,25$ & 0,00 & 0,00 & 0,00 \\
\hline $\mathrm{IHO} \times \mathrm{PR}$ & $20,08 * *$ & $-7,20 *$ & $20,90 *$ & 6,39 & $-4,86$ & $-50,37 * *$ & 0,49 & 0,00 & 0,00 \\
\hline $\mathrm{IHP} \times \mathrm{PR}$ & $25,93 * *$ & 0,80 & $27,91 * *$ & 1,93 & 3,14 & $-41,95$ & 0,28 & 0,00 & 0,00 \\
\hline
\end{tabular}

$*: \mathrm{P}<0.05 ; * *: \mathrm{P}<0.01 ; \mathrm{m}: \mathrm{F} 2$ nesline ait ortalamay1, a: Eklemeli gen etkisini, d: Dominans gen etkisini, aa: Eklemeli + Eklemeli gen etkisini, ad: Eklemeli+Dominans gen etkisini, dd: Dominans+Dominans gen etkisini, $\mathrm{H}^{2}$ : Geniş anlamda kalıtım derecesini, $\mathrm{h}^{2}$ : Dar anlamda kalıtım derecesini, Gí\%5: \%5'lik seleksiyon yoğunluğunda elde edilebilecek teorik ilerlemedir. 


\section{Heterosis Analizi Sonuçları}

Mısır 1slah çalışmalarında heterosis iki farklı şekilde değerlendirilmektedir. Heteroris analizlerinde anaç ortalamasına göre yapılan hesaplamada F1 neslindeki hibritin ebeveyn ortalamasına göre oransal farkı hesaplanır iken, üstün anaca göre heterosis hesaplamasında yüksek ortalamaya sahip anaca göre melezin performansı değerlendirilmektedir. Çalışmamızda ortalama heterosis ve heterobeltiosis değerleri, tek bitki verimi ve karotenoid içeriği için pozitif yönde, diğer özellikler için ise negatif yönde bulunmuştur. Bununla birlikte gerek hesaplama sonuçlarının büyüklüğü gerekse negatif pozitif yönde oluşuna göre ailelere göre dikkate değer farklar olduğu saptanmıştır. Aileler bazında yapılan heterosis analizi sonuçlarına göre, yağ oranı ve oleik asit için $\mathrm{Q} 2 \times \mathrm{PR}$ ve $\mathrm{IHO} \times \mathrm{PR}$, protein oran1 için $\mathrm{IHO} \times \mathrm{PR}$, lisin içeriği için $\mathrm{Q} 2 \times \mathrm{IHO}, \mathrm{Q} 2 \times \mathrm{IHP}$ ve $\mathrm{IHO} \times \mathrm{PR}$, triptofan içeriği için $\mathrm{IHO} \times \mathrm{PR}$ ve $\mathrm{IHP} \times \mathrm{PR}$, karotenoid içeriği için ise tüm ailelerde pozitif yönde heterosis hesaplanmıştır (Çizelge 5). Heterobeltiosis analiz sonuçlarına göre tek bitki verimi bakımından F1 hibritlerinin üstün anaçtan yüksek performansa sahip oldukları görülmüştür. Yağ oranı için Q2×PR, oleik asit içeriği için $\mathrm{IHO} \times \mathrm{PR}$, lisin içeriği için Q2 $\times$ IHP pozitif yönde heterobeltiosis değeri göstermiştir. Karotenoid içeriği için IHO $\times$ IHP dışında tüm ailelerde pozitif yönde heterobeltiosis değeri hesaplanmıştır (Çizelge 6).

Bilimsel çalışmalarda mısırda verim ve verim özelliklerinin pozitif heterosise sahip olduğu farklı çalışmalarda rapor edilmiştir (Bekele ve Rao, 2013). Buna karşım tane kalite özelliklerinde genel olarak negatif yönde heterosis olduğu kabul görmektedir. Ancak bu durum çalışmalarda kullanılan genetik materyal tarafından yüksek düzeyde etkilenen bir durumdur. Yapılan bazı çalışmalarda protein ve yağ oranı gibi birincil tane kalite özelliklerinin bazılarında negatif yönde (Bekele ve Rao, 2013), bazı çalışmalarda ise pozitif yönde heterosis olduğunun bildirilmesi bu durumu doğrulamaktadır (Al-Naggar ve ark., 2016). Çalışmamızda elde edilen bulgulara göre karotenoid içeriği için tüm materyallerde heterosis ve heterobeltiosis değerlerinin pozitif yönde bulunması da bu duruma bir örnektir. IHO ve IHP ebeveynleri beyaz taneli genotipler olduğundan, renkli taneli melezlerin tamamında yüksek heterosisi olduğu gözlenmiştir.

Çizelge 5. İncelenen özellikler için ailelere göre F1 nesline ait heterosis değerleri

\begin{tabular}{|c|c|c|c|c|c|c|c|}
\hline Populasyon & $\begin{array}{l}\text { Tek Bitki } \\
\text { Verimi }\end{array}$ & $\begin{array}{l}\text { Yağ } \\
\text { Oranı }\end{array}$ & $\begin{array}{l}\text { Protein } \\
\text { Oranı }\end{array}$ & Oleik Asit & $\begin{array}{l}\text { Lisin } \\
\text { İçeriği }\end{array}$ & $\begin{array}{l}\text { Triptofan } \\
\text { İçeriği }\end{array}$ & $\begin{array}{l}\text { Karotenoid } \\
\text { İçeriğ } i\end{array}$ \\
\hline $\mathrm{Q} 2 \times \mathrm{IHO}$ & 44,7 & $-10,41$ & $-4,49$ & $-2,05$ & 4,95 & $-28,9$ & 271,2 \\
\hline $\mathrm{Q} 2 \times \mathrm{IHP}$ & 88,4 & $-2,02$ & $-6,47$ & $-16,34$ & 2,53 & $-28,0$ & 310,2 \\
\hline $\mathrm{Q} 2 \times \mathrm{PR}$ & 58,2 & 3,12 & $-5,81$ & 1,98 & $-9,57$ & $-15,8$ & 203,0 \\
\hline $\mathrm{IHO} \times \mathrm{IHP}$ & 144,5 & $-7,27$ & $-16,86$ & $-7,92$ & $-3,76$ & $-15,9$ & 236,4 \\
\hline $\mathrm{IHO} \times \mathrm{PR}$ & 106,6 & 0,49 & 1,36 & 30,23 & 6,32 & 30,0 & 418,8 \\
\hline $\mathrm{IHP} \times \mathrm{PR}$ & 78,9 & $-7,51$ & $-13,89$ & $-22,65$ & $-10,19$ & 34,7 & 752,2 \\
\hline Ortalama & 80,5 & $-4,48$ & $-8,19$ & $-2,20$ & $-1,37$ & $-10,6$ & 335,3 \\
\hline
\end{tabular}

Çizelge 6. İncelenen özellikler için ailelere göre F1 nesline ait heterobeltiosis değerleri

\begin{tabular}{llllllll} 
& Tek Bitki & Yağ & Protein & Oleik & Lisin & Triptofan & Karotenoid \\
Populasyon & Verimi & Oranı & Oran1 & Asit & İçeriği & $\begin{array}{l}\text { İçeriği } \\
\text { İçeriği }\end{array}$ \\
\hline Q2 $\times$ IHO & 10,5 & $-38,2$ & $-10,9$ & $-14,1$ & $-6,5$ & $-31,6$ & 104,7 \\
Q2 $\times$ IHP & 22,3 & $-4,3$ & $-23,2$ & $-18,5$ & 1,7 & $-41,1$ & 126,2 \\
Q2 $\times$ PR & 8,6 & 1,7 & $-8,2$ & $-9,6$ & $-10,7$ & $-52,0$ & 133,6 \\
IHO $\times$ IHP & 91,4 & $-35,2$ & $-27,6$ & $-21,0$ & $-13,0$ & $-28,8$ & 236,4 \\
IHO $\times$ PR & 76,4 & $-31,2$ & $-3,1$ & 3,0 & $-7,8$ & $-25,2$ & 208,6 \\
IHP $\times$ PR & 60,9 & $-10,8$ & $-27,8$ & $-29,8$ & $-10,8$ & $-17,5$ & 406,9 \\
Ortalama & 36,8 & $-13,0$ & $-11,7$ & $-10,1$ & $-3,8$ & $-33,9$ & 244,9 \\
\hline
\end{tabular}

\section{Korelasyon Analizi Sonuçları}

Tüm veriler üzerinden hesaplanan korelasyon değerlerine göre verim ile protein oranı arasında negatif yönde bir korelasyon ( $\left.\mathrm{r}=0,21^{* *}\right)$ olduğu saptanmış, verim ile oleik asit, lisin içeriği, triptofan içeriği ve karotenoid içeriği arasında ise istatistiki olarak önemli pozitif yönde korelasyonlar hesaplanmıştır (Çizelge 7). Yağ oranı karotenoid içeriği dışında $\left(\mathrm{r}=-0,37^{* *}\right)$ diğer tüm özellikler ile pozitif yönde önemli korelasyona sahip olmuştur. Protein oranı ve oleik asit içeriği ile lisin ve triptofan içeriği arasındaki ilişkiler pozitif yönde bulunurken, bu özellikler ile karotenoid içeriği 
ÇOMÜ Zir. Fak. Derg. (COMU J. Agric. Fac.)

2021: 9 (1): 119-129

ISSN: 2147-8384 / e-ISSN: 2564-6826

doi: 10.33202/comuagri.870961

arasında negatif yönde korelasyonlar $\left(\mathrm{r}=-0,21^{* *} ; \mathrm{r}=-0,24 * *\right)$ hesaplanmıştır (Çizelge 7). Korelasyon analizi sonuçları, tüm veriler ve aileler bazında hesaplanan incelenen özellikler arası ilişkilerin özellik çiftlerine göre değiştiğini göstermiştir. Nitekim özellikler arasındaki ilişkilerin farklı genotiplere göre değişim gösterdiğini ortaya koyan çalışmalar da mevcuttur (Kahrıman ve ark., 2015c). Nitelikli genotiplerde tane kalite özellikleri normal genotiplere farklılık göstermekte ve bu özellikler bakımından barındırdıkları varyasyonda da önemli değişimler gözlenebilmektedir.

Çizelge 7. İncelenen özelliklerde tüm aileler ve ailelere göre hesaplanan korelasyonlar

\begin{tabular}{|c|c|c|c|c|c|c|}
\hline Tüm Popülasyonlar & Verim & Yăg & Protein & Oleik & Lisin & Triptofan \\
\hline Yağ & 0,07 & & & & & \\
\hline Protein & $-0,21 * *$ & $0,17 * *$ & & & & \\
\hline Oleik & $0,15^{* *}$ & $0,72 * *$ & $-0,00$ & & & \\
\hline Lisin & $0,09 *$ & $0,71 * *$ & $0,39 * *$ & $0,48 * *$ & & \\
\hline Triptofan & $0,14 * *$ & $0,53 * *$ & $0,34 * *$ & $0,41 * *$ & $0.65 * *$ & \\
\hline Karotenoid & $0,11 * *$ & $-0,37 * *$ & $-0,21 * *$ & $-0,24 * *$ & $-0.37 * *$ & $-0,28 * *$ \\
\hline Q2xIHP & Verim & Yağ & Protein & Oleik & Lisin & Triptofan \\
\hline Yağ & 0,07 & & & & & \\
\hline Protein & $-0,55 * *$ & 0,07 & & & & \\
\hline Oleik & $0,31 * *$ & $0,39 * *$ & $-0,51 * *$ & & & \\
\hline Lisin & $-0,03$ & $0,27 * *$ & $0,36 * *$ & $-0,18$ & & \\
\hline Triptofan & $-0,15$ & 0,11 & 0,14 & $-0,10$ & $0,42 * *$ & \\
\hline Karotenoid & $0,22 *$ & 0,04 & $-0,23 *$ & 0,06 & $-0,24 *$ & $-0,58 * *$ \\
\hline Q2xPR & Verim & Yağ & Protein & Oleik & Lisin & Triptofan \\
\hline Yağ & $0,23^{*}$ & & & & & \\
\hline Protein & 0,04 & 0,15 & & & & \\
\hline Oleik & $0,31 * *$ & $0,44 * *$ & 0,08 & & & \\
\hline Lisin & 0,06 & 0,11 & $0,22 *$ & $0,23^{*}$ & & \\
\hline Triptofan & $0,37 * *$ & 0,13 & 0,07 & $0,35 * *$ & $0,33 * *$ & \\
\hline Karotenoid & 0,16 & 0,02 & $-0,56^{* *}$ & $-0,19 *$ & $-0,29 * *$ & $-0,07$ \\
\hline IHOxIHP & Verim & Yağ & Protein & Oleik & Lisin & Triptofan \\
\hline Yağ & 0,12 & & & & & \\
\hline Protein & $-0,32 * *$ & $-0,36 * *$ & & & & \\
\hline Oleik & $-0,03$ & $0,60 * *$ & $-0,54 * *$ & & & \\
\hline Lisin & 0,08 & $0,65 * *$ & $0,20 *$ & $0,21 *$ & & \\
\hline Triptofan & $-0,07$ & $0,53 * *$ & $0,19 *$ & 0,15 & $0,71 * *$ & \\
\hline Karotenoid & $-0,02$ & $-0,52 * *$ & $-0,06$ & $-0,15$ & $-0,42 * *$ & $-0,45^{* *}$ \\
\hline IHOxPR & Verim & Yağ & Protein & Oleik & Lisin & Triptofan \\
\hline Yağ & 0,09 & & & & & \\
\hline Protein & 0,10 & $0,42 * *$ & & & & \\
\hline Oleik & 0,08 & $0,71 * *$ & 0,17 & & & \\
\hline Lisin & 0,05 & $0,83 * *$ & $0,49 * *$ & $0,60 * *$ & & \\
\hline Triptofan & 0,18 & $0,78 * *$ & $0,31 * *$ & $0,57 * *$ & $0,74 * *$ & \\
\hline Karotenoid & $0,26 * *$ & $-0,29 * *$ & $-0,44 * *$ & $-0,14$ & $-0,32 * *$ & $-0,09$ \\
\hline IHPxPR & Verim & Yağ & Protein & Oleik & Lisin & Triptofan \\
\hline Yağ & 0,09 & & & & & \\
\hline Protein & $-0,14$ & 0,10 & & & & \\
\hline Oleik & $-0,02$ & 0,15 & 0,02 & & & \\
\hline Lisin & 0,06 & $0,27 * *$ & $0,33 * *$ & $-0,08$ & & \\
\hline Triptofan & 0,15 & $0,28 * *$ & $0,53 * *$ & 0,05 & $0,47 * *$ & \\
\hline Karotenoid & 0,15 & $-0,13$ & 0,02 & $-0,05$ & $-0,25 * *$ & $0,44 * *$ \\
\hline IHPxPR & Verim & Yağ & Protein & Oleik & Lisin & Triptofan \\
\hline Yağ & 0,09 & & & & & \\
\hline Protein & $-0,14$ & 0,10 & & & & \\
\hline Oleik & $-0,02$ & 0,15 & 0,02 & & & \\
\hline Lisin & 0,06 & $0,27 * *$ & $0,33 * *$ & $-0,08$ & & \\
\hline Triptofan & 0,15 & $0,28 * *$ & $0,53 * *$ & 0,05 & $0,47 * *$ & \\
\hline Karotenoid & 0,15 & $-0,13$ & 0,02 & $-0,05$ & $-0,25 * *$ & $0,44 * *$ \\
\hline
\end{tabular}

$*: p<0.05 ; * *: p<0.01$ 
Genel kanı olarak tek bitki verimi ile tane kalite özelliklerinin birlikte geliştirilmesinin zor olduğu kabul edilmektedir. Ancak araştırmamızda kullanılan materyallerden bazıların tek bitki verimi ile bazı tane kalite özelliklerinin birlikte artırılabileceği görülmüştür. Korelasyon analizleri özellik düzeyinde bağlantıları görtermesine karşın bu analizler ailelere göre yapıldığında kullanılan materyalin sslah çalışmalarında kullanımı konusunda daha detaylı sonuçlar verebilmektedir. $\mathrm{Bu}$ sonuçların gen etkileri analizlerine ait bulgularla birlikte değerlendirilmesinde yarar vardır.

\section{Sonuç}

$\mathrm{Bu}$ çalışmanın amaçlarına göre, elde edilen sonuçları üç farklı konu başlı̆̆ altında değerlendirmek mümkündür. Bunlar; incelenen özelliklerin değişiminde rol oynayan gen etkileri ile seleksyonla ilerleme kaydedilebilecek materyaller, incelenen özelliklerde heterosis durumunu ve özellikler arasındaki ilişkilerdir.

İncelenen özelliklerle ilgili hesaplanan gen etkileri dikkate alındığında, verim için eklemeli etkilerle birlikte epistatik interaksiyonların etkili olduğu, karotenoid içeriği dışında diğer tane kalite özellikleri için de eklemeli gen etkilerinin özelliklerin değişiminde rol oynadığı belirlenmiştir. Kullanılan ailelerde tane veriminin seleksiyon ile geliştirilebileceği ve en yüksek ilerlemenin Q2 $\times$ PR'den elde edilebileceği görülmüştür. Tane kalite özelliklerinden yağ oranı için $\mathrm{IHO} \times \mathrm{PR}$ ve $\mathrm{IHP} \times \mathrm{PR}$, oleik asit içeriğini artırmak amacıyla $\mathrm{Q} 2 \times \mathrm{IHO}, \mathrm{IHO} \times \mathrm{PR}$ ve $\mathrm{IHP} \times \mathrm{PR}$, protein oranı için $\mathrm{Q} 2 \times \mathrm{PR}$ ve $\mathrm{IHO} \times \mathrm{PR}$, lisin içeriği için $\mathrm{IHP} \times \mathrm{PR}$, triptofan içeriği için $\mathrm{Q} 2 \times \mathrm{PR}, \mathrm{IHO} \times \mathrm{PR}$ ve $\mathrm{IHP} \times \mathrm{PR}$, karotenoid içeriği için $\mathrm{Q} 2 \times \mathrm{IHO}, \mathrm{IHO} \times \mathrm{IHP}, \mathrm{IHO} \times \mathrm{PR}$ ve $\mathrm{IHP} \times \mathrm{PR}$ popülasyonlaronnda pozitif yönde genetik ilerlemenin mümkün olduğu anlaşılmıştır.

Heterosis analizleri tane verimi ve karotenoid içeriği için ortalama heterorsis ve heterobeltiosis değerlerinin pozitif yönde olduğunu göstermiştir. Heterosis değerlerinin büyüklüğü ailelere göre değişim göstermiştir. Aileler bazında yapılan heterosis analizi sonuçlarına göre, yağ oranı ve oleik asit için $\mathrm{Q} 2 \times \mathrm{PR}$ ve $\mathrm{IHO} \times \mathrm{PR}$, protein oranı için $\mathrm{IHO} \times \mathrm{PR}$, lisin içeriği için $\mathrm{Q} 2 \times \mathrm{IHO}, \mathrm{Q} 2 \times \mathrm{IHP}$ ve $\mathrm{IHO} \times \mathrm{PR}$, triptofan içeriği için $\mathrm{IHO} \times \mathrm{PR}$ ve $\mathrm{IHP} \times \mathrm{PR}$, karotenoid içeriği için ise tüm ailelerde pozitif yönde heterosis hesaplanmıştır. Heterobeltiosis analiz sonuçlarına göre tek bitki verimi bakımından F1 hibritlerinin üstün anaçtan yüksek performansa sahip oldukları görülmüştür.

İncelenen özellikler arası ilişkiler dikketa alındığında, aile düzeyinde hesaplanan korelasyonlar ile tüm veriler üzerinden hesaplanan korelasyonlar arasında önemli farklar olduğu görülmüştür. Tüm veriler üzerinden hesaplanan korelasyon katsayıları ile aileler bazında hesaplanan korelasyonlarda özellik çiftlerine göre farklılıklar olduğu tespit edilmiştir. Korelasyon analizleri tane verimi ile birlikte bazı tane kalite özelliklerinin geliştirilebileceğine işaret etmiştir. Genel kanının aksine tek bitki verimi ile birlikte bazı kalite özelliklerinin geliştirilebileceği görülmüştür.

Çalışmada öne çıan materyaller tane kalitesine yönelik yürütülecek ıslah programlarına dahil edilebilir. Bu materyallerle ilgili daha kapsamlı bilgiler elde etmek amacıyla açılım nesillerinin farklı daha fazla sayıda bitki ile test edilmesinde yarar vardır. Bu çalışmada ele alınan özellikler dışında gerek endüstriyel gerekse beslenme açısından önem taşıyan farklı tane kalite özellikleri için benzer araştırmaların yürütülmesi ulusal ıslah programları bakımından faydalı olacaktır.

Not

Bu makale Ziraat Yüksek Mühendisi Halil Uysal'ın yüksek lisans tez çalışmasından derlenmiştir. Bu çalışma Çanakkale Onsekiz Mart Üniversitesi Bilimsel Araştırma Projeleri Koordinasyon Birimince Desteklenmiştir. Proje Numarası: FYL-2018-2522.

\section{Kaynaklar}

Al-Naggar, A.M.M., Atta, M.M.M., Ahmed, M.A., Younis, A.S.M., 2016. Heterosis and combining ability of maize (Zea mays $L$.) grain protein, oil and starch content and yield as affected by water stress. Archives of Current Research International. 4(4), 1-15.

Anonim, 2016. Controlled Pollination in Maize, Schnable Lab Protocols. [online] Erişim Adresi: http://schnablelab.plantgenomics.iastate.edu/resources/pollination

Bekele, A., Rao, T.N., 2013. Heterosis study for grain yield, protein and oil improvement in selected genotypes of maize (Zea mays L.). Journal of Plant Science. 1(4):57-63.

Egesel, C. Ö., Kahriman F., Gül M. K., 2011. Discrimination of maize inbreds for kernel quality traits and fatty acid composition by a multivariate graphical technique. Acta Scientiarum Agronomy. 33, 613-620. 
Egesel, C.Ö., Kahriman, F., 2012. Determination of quality parameters in maize by NIR reflectance spectroscopy. Journal of Agricultural Sicences. 18: 43-53.

Egesel, C. Ö., Kahrıman, F., Ekinci, N., Kavdır, İ., Büyükcan, M. B., 2016. Analysis of fatty acids in kernel, flour, and oil samples of maize by nır spectroscopy using conventional regression methods. Cereal Chemistry, 93: 487-492.

Falconer, D.S., Mackay, F.C., 1996. Introduction to quantitative genetics. Fourth Edition. Longman. Newyork.

Galicia, L., Nurit, E., Rosales, A., Palacios-Rojas, N., 2009. Laboratory protocols. Maize nutrition quality and plant tissue analysis laboratory. CIMMYT 2009, 42.

Gusmini G, Whener TC, Donaghy SB (2007). SASQuant: A SAS software program to estimate genetic effects and heritabilities of quantitative traits in populations consisting of 6 related generations. Journal of Heredity 98: 345-350.

Haq, M.I.U., Ajmal, S., Kamal, N., Khanum, S., Siddique, M., Kiani, M. Z., 2013. Generation mean analysis for grain yield in maize. The Journal of Animal \& Plant Sci. 23(4): 2013, Page: 1146-1151.

Howe, J. A., Tanumihardjo, S. A., 2006. Carotenoid-biofortified maize maintains adequate vitamin A status in Mongolian gerbils. Journal of Nutrition. 136: 2562-2567.

Hussain, M., Kiani, T.T., Shah, K.N., Ghafoor, A., Rabbani, A., 2015. Gene action studies for protein quality traits in Zea mays 1. under normal and drought conditions, Pak. J. Bot., 47(1): 57-61.

Kahrıman, F., Egesel, C.Ö., Cebeci, R., Demir, A., Bayraktar, S., 2015a. Genetic analysis of flowering in maize based on calendar and thermal time. YYU Tar Bil Derg, 25(2), 193- 199.

Kahriman, F., Egesel C.Ö., Onaç İ., 2015b. A preliminary study for determination of the possibility of simultaneous selection for oil content and grain yield in maize. Maydica, 60, M4.

Kahrıman, F., Egesel, C.Ö. Egesel, B., 2015c. A comparative study on changes and relationships of kernel biochemical components in different types of maize. J. Am Oil Chem Soc. 92:1451-1459.

Kahrıman, F., Egesel, Ö., C. 2017. Heterosis and heritability analyses for plant yield and some quality traits in F1 and F2 generations of maize. Anadolu Tarım Bilim. Derg./Anadolu J Agr Sci. 32(2): 237-243.

Lopez-Martinez, L. X., Oliart-Ros, R. M., Valerio-Alfaro, G., Lee, C. H., Parkin, K. L., Garcia, H. S., 2009. Antioxidant activity phenolic compounds and anthocyanins content of eighteen strains of Mexican maize. LWT Food Sci. Technol. 42:1187-1192.

Ma, X. Q., J.H. Tang, W.T. Teng, J.B. Yan, Y.L. Meng and J.S. Li. (2007). Epistatic interaction is an important genetic basis of grain yield and its components in maize. Molecular Breeding, 20(1): 41-51.

Mather, K., Jinks, J. L., 1982. Biometrical Genetics. 3rd Edition, Chapman and Hall, London, PP. 396.

Mbogo, O.P., Dida, M.M., Owuor, B., 2015. Generation means analysis for estimation of genetic parameters for striga hermonthica resistance in maize (Zea mays L.). Journal of Agricultural Science. 7(8):143-155.

MGM, 2019. İklim Verileri. Meteoroloji Genel Müdürlüğü, Ankara.

Obeng-Bio, E., Badu-Apraku, B., Ifie, B.E., Danquah, A., Blay, E.T., Annor, B., 2019. Genetic analysis of grain yield and agronomic traits of early provitamin A quality protein maize inbred lines in contrasting environments. The Journal of Agricultural Science. 157:413-433.

Öz, A., Kapar, H., 2007. Mısırın yağ içeriği ve yağ sanayi açısından önemi. 1.Ulusal Yağlı Tohumlu Bitkiler ve Biyodizel Sempozyumu, 28-31 Mayis 2007, Samsun, 388-391.

Panfili, G., Fratianni, A., Irano, M., 2004. Improved normal-phase highperformance liquid chromatography procedure for the determination of carotenoids in cereals. Public Health Nutr. 52:6373-6377.

Patil, K.H., Mahajan, R.C., Rani C.L., 2016. Generation mean analysis for grain yield attributing traits in maize (Zea mays L.). Green Farming, 7(2): 277-282.

Pollak, L., Scott, M. P., 2005. Breeding for grain quality traits. Maydica, 50:247-257.

Rodriguez-Amaya, D.B., Kimura, M., 2004. HarvestPlus handbook for carotenoid analysis. HarvestPlus Technical Monograph Series 2. IFPRI, Washington, D.C., and CIAT, Cali.

SAS Institute., 1999. SAS V8 User Manual, Cary, NC.

Shahrokhi, M., Khorasani, S.K., Ebrahimi, A., 2011. Generation mean analysis for yield and yield component in maize (Zea mays L.). J. of plant Physiology and breeding.1(2): 59-72.

Sher, H., Iqbal, M., Khan, K., Yasir, Y., Rahman, H., 2012. Genetic analysis of maturity and flowering characteristics in maize (Zea mays L.). Asian Pacific Journal of Tropical Biomedicine 2: 621-626.

Sofi, P., Rather, A.G., Venkatesh, S., 2006. Detection of epistasis by generation means analysis in maize hybrids. Pak. J. Biol. Sci. 9(10):1983- 1986.

TTSM, 2010. Tohumluk Tescil ve Sertifikasyon Müdürlüğü, Tarımsal değerleri ölçme denemeleri teknik talimat1: Misır, Ankara.

Vasal, S.K., 2000. High quality protein corn. In: Hallauer AR (ed) Specialty corns, 2nd edn. CRC Press, Boca Raton

Yayar, R., Bal, H.S.G., 2007. Forecasting of corn oil price in Turkey. Journal of Applied Science Research. 3(8): 706-712. 